\title{
PROFIT AND LOSS SHARING IN THE PARTNERSHIP AGREEMENT UNDER THE NEW ROMANIAN CIVIL CODE
}

\author{
A.V.Singh \\ Amelia - Veronica Singh \\ Faculty of Law and Administrative Sciences \\ University of Pitesti, Piteşti, Romania \\ *Correspondence: Amelia Singh, University of Pitesti, Faculty of Law and Administrative \\ Sciences, 71 Republicii Avenue, Pitesti, Arges, Romania \\ E-mail: singh.amelia@yahoo.com
}

\begin{abstract}
The new Romanian Civil Code regulations have reconfirmed the rule of proportionality when speaking about profit and loss in a partnership agreement. Basically, the law does not require that the participation of partners in profit and loss be necessarily proportional to their contribution to the society's capital and the associates can even determine their share of benefits and losses. In case the associates establish by contract only their share of benefits, then their contribution to losses will become proportional to their profit share. If the share of profit is not proportionally equal with the contribution, then the contribution to debts will be proportional with the profit share and not with the contribution brought to the capital.

One must keep in mind as compulsory the condition that each partner should participate both in profit and loss sharing. On the one hand, a partner cannot reserve all the benefit for himself only, while on the other hand the partners cannot decide that one or several of them are exempted from participating in loss sharing. Also, they cannot set a provision by which a partner is excluded wither from profit sharing or from participation in loss, as this provision would be void ab initio.
\end{abstract}

Key-words: profit sharing, loss sharing, essential condition, rule of proportionality

\section{Introduction}

By adopting the current Civil Code ${ }^{l}$, the Romanian legislator has considered appropriate to review the rules of civil society which have become obsolete and to replace them with flexible regulations which, by reconsidering the civil society, could provide those interested with an effective legal framework for profit association, instead of the classical trade association. In the light of the new Civil Code, by means of a partnership agreement, two or more people mutually engage to cooperate in an activity and to bring contributions in cash, assets, specific knowledge or services, in order to share the profit or to make use of the resulting savings (article 1881, paragraph 1, the Civil Code); this right has a correlative obligation to take the company's losses.

Thus, profit and loss sharing, whatever its value, represents an essential condition for the existence of the company and also a distinctive feature of the partnership agreement in comparison with other types of private legal entities ${ }^{2}$.

\footnotetext{
${ }^{1}$ Law no. 287/2009 concerning the Civil Code was published in the Romanian Official Monitor no. 511/24 July 2009, part I. The law was adopted on June 25 2009, based on the provisions of article 114 paragraph 3 from the republished Constitution, following the Government's engagement in front of the Senate and Deputy Chamber, reunited in common session on June 222009.

${ }^{2}$ Alexis Constantin, Droit des sociétés, 4-e édition, Mementos Dalloz, 2010, p. 33.
} 
This distinctive feature, although not necessarily specified, represents the expression of two Roman law principles, according to which "any contract/agreement involves loss sharing" (Cum societas contrahitur tam lucri, quam damni communio inizur) ${ }^{3}$ and ,it is right for those who participated in gaining to be also part in losing" (Aequum est cujus participavit lucrum, participet et damnum $)^{4}$. While applying this concept, the jurisprudence considered that ,the essence of a partnership agreement is to make all contracting parties share both profit and losses resulted from the activity which represents the object of the contract"s.

The mere stipulation of a fixed amount of money for price and also of a share of the eventual profit obtained by the buyer after selling any purchased goods is not enough to change the nature of the sales contract ${ }^{6}$ or to turn it into a partnership agreement, because the element of loss risk for the seller is missing.

Profit and loss sharing can be done both when the partnership agreement is terminated and while it is still functioning. This is also provided in article 721 from the German Civil Code - the partners can ask for the conclusion of calculations and for the profit and loss sharing only at the dissolution of the partnership, according to paragraph 1 , or, if the company has invested on long term, calculations and profit sharing must be done at the end of the financial year, according to paragraph 2. Profit or loss is calculated by making the difference between patrimony on the one hand, and liabilities and capital on the other hand. By profit/benefit we understand the excess of common patrimony in terms of debts and equity. A compensation for loss can be required only during partner confrontation, because there is no such thing as anticipated additional payment obligation for partners. ${ }^{7}$

In the Romanian 1864 Civil Code, in the absence of a special provision in the partnership agreement, each partner's share of profit and loss (including its share of company costs - article 1517 from the Civil Code) was established using the rule of proportionality stipulated in article 1511 paragraph 1 from the Civil Code, according to which "that share will be proportional to each partner's contribution to the common patrimony". The provisions of article 1511, paragraph 1 from the Civil Code, proposing the criterion of proportionality, has a suppletive value, therefore the partners could agree on sharing profits and losses based on their own criteria. The French Civil Code has similar provisions, stipulating that profit and loss sharing is, in principle, proportional to the value of the contribution to the capital. Still, the agreement's regulations can stipulate otherwise, within the limits of interdiction of leonine provisions.

The need to ensure that all partners enjoy a real equal treatment, both in terms of their partnership's functioning, and in terms of profit and loss sharing, has led to the amendment of all conventions violating this principle.

The current Civil Code gives a greater importance to regulations concerning the participation in benefits and losses, while reuniting and completing the provisions of article 1511 and article 1513 from the 1864 Civil Code within the six paragraphs of article 1902, which is actually called "Profit and loss sharing".

The provisions of article 1902 paragraph 1 state the validity condition that is the very essence of the partnership agreement, that is the right of every partner to take part in the obtained profit is correlated to the obligation to bear the eventual losses. As in the previous Civil Code, article 1902 paragraph 2 reaffirms the rule of proportionality for the situations

\footnotetext{
${ }^{3}$ Pr. Digeste, Pro Socio, 17,2 in D.Iancu, C.Gălățanu, Drept privat roman, University’s Publishing House, Pitesti, 2009.

${ }^{4}$ Ibidem.

5 Jurisprudența Română, 1930, p. 23.

${ }^{6}$ Cas. III, dec. nr. 1522/06.11.1929, in Buletinul de decizii, Bucharest, 1929, p. 579.

7 Peter Kindler, Grundkurs Handels- und Gesellschaftrecht, University of Augsberg, C.H. Beck Publishing House, Munchen, 2011, p. 262.
} 
where the parties involved have not decided otherwise: every partner will have a share of profit and loss proportional to his contribution to the capital. Following the same paragraph 2 of article 1902, in order to understand correctly its provisions, we must highlight the fact that there is a spelling error, in the sense that the term "rapport" is used instead of „,contribution"; therefore, the correct sentence is "Profit and loss share of the partner whose contribution is...". Thus, in the situation where the contribution of a partner to the capital consists of expertise/knowledge or services, his profit and loss share is equal to the share of the partner with the smallest material contribution, unless the partners have already decided otherwise.

Basically, the law does not impose that partner participation in benefits and losses are compulsorily proportional to their contribution to the capital, as the partners can establish by themselves their share of profit and loss. In case they establish only their profit share in the contract, their loss share will be proportional to their profit share. If the profit sharing is not proportional to the contribution, the loss sharing will become proportional to the profit sharing instead the contribution to the capital ${ }^{8}$.

Note that it is compulsory for each partner to participate in both profit and loss sharing. On the one hand, a partner is not allowed to keep all the profit for himself, while on the other hand, the partners cannot decide that one or several of them should be exempted from loss sharing. Also, the partners cannot introduce a provision excluding one of them either from profit or loss sharing, as this type of provision is void ab initio. These are known in the specialized literature as "leonine provisions"; they contradict the very essence of the partnership agreement and are absolutely void.

To this end, article 1513 from the Civil Code deems void the contract containing a leonine provision, by which a partner either keeps the whole profit to himself or is exempted from loss sharing ${ }^{10}$; this is also mentioned by article 1902 paragraph 5, which stipulates that "any provision by which a partner is excluded from profit or loss sharing is considered unwritten/inexistent".

The Civil Code terms explain the general character of the rule according to which any type of stipulation mentioned above is void, without making a distinction whether it is included in the articles of association or in a separate document related to the partnership agreement, whether the provision is temporary or spins over an undetermined period of time.

Such a provision (societas leonina) was deemed ever since the Roman law as being contra naturam societatis.

Some authors have considered that, in the case of a leonine provision, the whole contract is void" ${ }^{11}$, since "in a partnership agreement, all the provisions introduced by the partners are closely related and if one of them cannot produce effects, then all the legal arrangement collapses (...)".

According to most opinions in the legal literature and practice, the leonine provision does not entail the nullity of the entire partnership agreement; instead it is sanctioned only by partial nullity ${ }^{12}$. Consequently, the provision is considered unwritten, as it is contrary to jus

\footnotetext{
${ }^{8}$ New Civil Code, Fl.A. Baias and the collective authors - Comentarii, doctrină şi jurisprudență, vol. III, Hamangiu Publishing House, Bucharest, 2012, p. 290.

${ }^{9}$ T. Prescure, A. Ciurea, Contracte civile, Hamangiu Publishing House, Bucureşti, 2007, p. 419.

${ }^{10}$ See D.C.C. nr. 744/24 iunie 2008, in the Official Monitor no. 570/29 July 2008 in V.Terzea, Coduri adnotate - Codul civil, vol. III, C.H.Beck Publishing House, Bucureşti, 2009, p. 77 - the provisions of the indicated article cannot distinguish and do not impose a certain way of dealing with a leonine provision, therefore the court can appreciate if the formulation of the contract's terms really results from such a provision, even if it is not explicitly stated; also see S. Deleanu, Clauza leonină în contractele de societate, in „Law” magazine no. 2/1992, p. 38.

${ }^{11}$ C. Prieto, Conventions extra-statutaires entre associes, p. 387.

12 See also Daniel Mihai Şandru, Pacte societare. Clauze, pacte, înțelegeri între asociații societăților comerciale, Universitarian Publishing House, Bucharest, 2010, p. 55.
} 
fraternitatis, which is common to all agreements. This opinion is also supported by the provisions of article 1844-1 from the French Civil Code, according to which any stipulation (and not the entire contract) reserving all the profit to one partner or totally exempting him from loss sharing is invalid, as well as the provisions which totally exclude a partner from profit sharing or make him bear all the losses on his own. The legal assessment of the interdiction has in view the assessment of the critical, uncertain threshold pertaining to the sovereign power of judges at first instance. The interdiction does not apply to the case when partners give up their dividends they are entitled to at the end of the financial year, nor to cases when engagements to purchase social rights (even those established by the partners) are being made, by which the buyer can set a fix price for the seller. ${ }^{13}$

The interdiction of leonine provisions does not exclude the right of the partners to establish a disproportionate share of profit and loss (that is disproportionate as compared to the contribution to the capital), on condition that the agreement stays within the law in force ${ }^{14}$. One can also stipulate that a partner who has contributed with certain services can be exempted from loss sharing in terms of patrimony, his participation to losses being reduced to the benefits of the service he has provided.

Without being considered leonine, any other provision can be abusive if it is susceptible of violating the equity principles between the partners. As a general rule, an abusive provision represents ,any condition or conjunction of terms and conditions which generates an obvious imbalance between the rights and the obligations of the parties", thus allowing a right to be exerted to an end which contradicts its legal purpose. Such a provision, which is similar to a leonine provision, will become void without affecting the validity of the partnership agreement.

In agricultural partnership agreements established under article 5 from the Law no. $36 / 1991$, any inequitable provision granting "special rights to certain partners" is prohibited (article 13); in case of prohibition breaching, the agreement will become partially void, in order to sanction the respective provision.

\section{Conclusions}

1. Profit and loss sharing, whatever its value, represents an essential condition for the existence of the company and also a distinctive feature of the partnership agreement in comparison with other types of private legal entities.

2. The Current Civil Code reaffirms the rule of proportionality for the situations where the parties involved have not decided otherwise.

3. Profit and loss sharing can be done both when the partnership agreement is terminated and while it is still functioning.

4. Any provision by which a partner is excluded from profit or loss sharing is considered unwritten/inexistent. The interdiction of leonine provisions does not exclude the right of the partners to establish a disproportionate share of profit and loss (that is disproportionate as compared to the contribution to the capital), on condition that the agreement stays within the law in force.

\section{Bibliography}

Noul Cod Civil, Fl.A. Baias and the collective authors- Comentarii, doctrină şi jurisprudență, vol. III, Hamangiu Publishing House, Bucharest, 2012;

\footnotetext{
${ }^{13}$ Alexis Constantin, op. cit., p. 34.

${ }^{14}$ In the case of joint venture contracts, no legal provision can impose equal profit or loss sharing, since it might contradict the parties' free will and it might ignore the dispositive character of the rules guverning this form of association contract - see Decision no. 1851/26 March 2003 of the High Court of Cassation and Justice, Commercial Division, in RDC no. 12/2004, p. 232-234.
} 
Peter Kindler, Grundkurs Handels- und Gesellschaftrecht, University of Augsberg, C.H. Beck Publishing House, Munchen, 2011;

Alexis Constantin, Droit des sociétés, 4-e édition, Mementos Dalloz, 2010;

Daniel Mihai Şandru, Pacte societare. Clauze, pacte, înțelegeri între asociații societăților comerciale, Universitarian Publishing House, Bucharest, 2010;

D. Iancu, C.Gălățanu, Drept privat roman, Pitesti University`s Publishing House, 2009;

V. Terzea, Coduri adnotate - Codul civil, vol. III, C. H. Beck Publishing House, Bucharest, 2009; July 2009;

Law no. 287/2009 regarding the Civil Code, published in Official Journal no. 511/24

T. Prescure, A. Ciurea, Contracte civile, Hamangiu Publishing House, Bucharest, 2007 ;

Decision no. 1851/26 March 2003 of the High Court of Cassation and Justice, Commercial Section, in the Journal Revista de drept comercial no. 12/2004

S. Deleanu, Clauza leonină în contractele de societate, in "Dreptul" Journal no. 2/1992. 